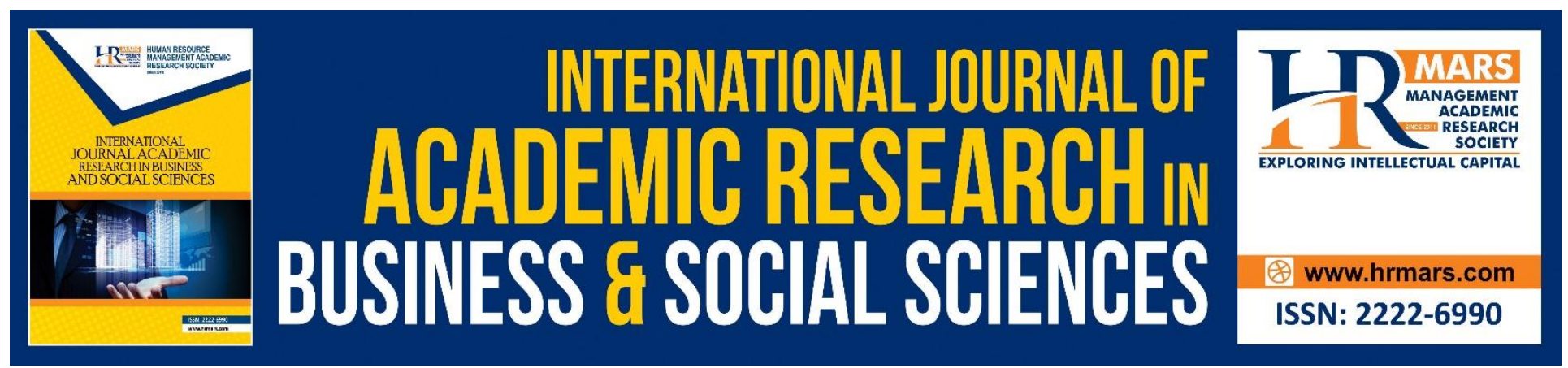

\title{
Application of Ca-Markov Model for the Analysis of Urban Growth in Kenyir Basin
}

Kabir Abdulkadir Gidado, Mohd Khairul Amri Kamarudin, Mousa Hammad Sulaiman Abu Ghurah, Noorjima Abd Wahab, Muhammad Hafiz Md Saad, Farouk Garba, Surachate Hakparn, Kanittha Lertbunchardwong, Tepvisit Potikengrith

To Link this Article: http://dx.doi.org/10.6007/IJARBSS/v9-i2/5579

DOI: $\quad 10.6007 /$ IJARBSS/v9-i2/5579

Received: 03 Jan 2019, Revised: 12 Feb 2019, Accepted: 27 Feb 2019

Published Online: 01 March 2019

In-Text Citation: (Gidado et al., 2019)

To Cite this Article: Gidado, K. A., Kamarudin, M. K. A., Ghurah, M. H. S. A., Wahab, N. A. H. M. S., Garba, F., Hakparn, S., ... Potikengrith, T. (2019). Application of Ca-Markov Model for the Analysis of Urban Growth in Kenyir Basin. International Journal of Academic Research in Business and Social Sciences, 9(2), 449-458.

Copyright: (C) 2019 The Author(s)

Published by Human Resource Management Academic Research Society (www.hrmars.com)

This article is published under the Creative Commons Attribution (CC BY 4.0) license. Anyone may reproduce, distribute, translate and create derivative works of this article (for both commercial and non-commercial purposes), subject to full attribution to the original publication and authors. The full terms of this license may be seen at: http://creativecommons.org/licences/by/4.0/legalcode

Vol. 9, No. 2, 2019, Pg. 449 - 458

Full Terms \& Conditions of access and use can be found at http://hrmars.com/index.php/pages/detail/publication-ethics 


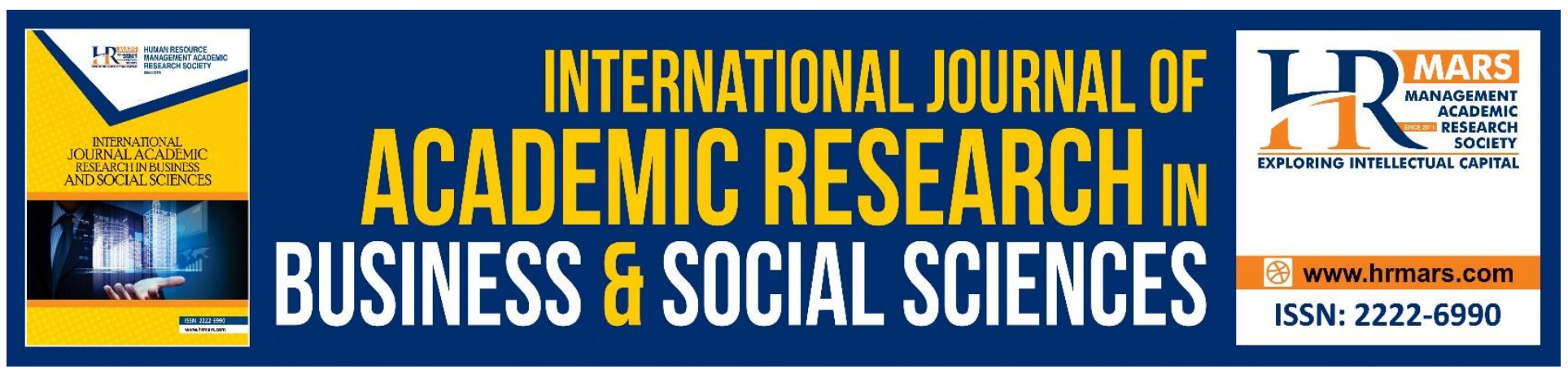

\title{
Application of Ca-Markov Model for the Analysis of Urban Growth in Kenyir Basin
}

\author{
${ }^{1}$ Kabir Abdulkadir Gidado, *1 Mohd Khairul Amri Kamarudin, ${ }^{1}$ Mousa \\ Hammad Sulaiman Abu Ghurah, ${ }^{1}$ Noorjima Abd Wahab, \\ 1,2Muhammad Hafiz Md Saad, ${ }^{3}$ Farouk Garba, ${ }^{4}$ Surachate Hakparn, \\ ${ }^{5}$ Kanittha Lertbunchardwong, ${ }^{6}$ Tepvisit Potikengrith \\ ${ }^{1}$ East Coast Environmental Institute (ESERI), Universiti Sultan Zainal Abidin, Kampus Gong Badak, \\ 21300 Terengganu, Malaysia. \\ ${ }^{2}$ AB Bakti Enterprise, Lot $27215 \mathrm{Kg}$. Gong Kuin 2, Jalan Tok Jembal, 21300 Kuala Nerus, Terengganu, \\ Malaysia. \\ ${ }^{3}$ Department of Geography Federal University Dutsin-Ma, Katsina State, Nigeria \\ ${ }^{4}$ Tourist Police Bureau, Bangkok, Thailand. \\ ${ }^{5}$ Faculty of Social Sciences and Humanities, Mahidol University, Nakhon Pathom, Bangkok, Thailand. \\ ${ }^{6}$ Special Branch Police Bureau, Bangkok, Thailand. \\ Email: *mkhairulamri@unisza.edu.my (Corresponding author)
}

\begin{abstract}
The Modelling and Simulation of land cover change are fundamental to the evaluation of successive environmental effects. Remote Sensing and Geographical Information System (GIS) give major procedures which can be valuable in the analysis at the town locale as well as the city levels. The study project the future land use change of Kenyir Basin in Hulu Terengganu. RS data from Thematic Mapper sensor of 2000, 2009 and Operational Land Imager of 2016 were used for the analysis. The study used supervised classification technique for classification, and Cellular Automata Markovian (CA-Markov) Model analysis was used for future projection of 2030. The result classified water body, vegetation and urban area. Modelling analysis reveals a continuous pattern of urban growth in the Kenyir Basin from $5.04 \mathrm{~km}^{2}, 79.51 \mathrm{~km}^{2}, 117.03 \mathrm{~km}^{2}$ and $220 \mathrm{~km}^{2}$ in the years 2001, 2009, 2016 and the projected the year 2030 with $0.6934 \mathrm{~K}$-standard value of stimulation. This study gives a chance to characterise and apply better methodologies for environmental management of land use to make improved coordination between urban growths, and conservation of natural environment.
\end{abstract}

Keywords: Environment, GIS, Land Use, Remote Sensing, Urban, Thematic Mapper sensor. 


\section{Introduction}

The land use and land cover change has been fast-tracking because of Socio-Economic drivers (Behera et al., 2012) and are firmly connected with sustainable development since they influence fundamental parts of the economic growth, for example, vegetation, and water resources (Islam \& Ahmed, 2011) and human life (Wahab et al., 2016; Verburg et al., 2004). Specialists from various disciplines have lately addressed the problem related to land-use change and comprehended the causes of land use change and investigate the level and area of future land use changes (Verburg et al., 2004; Lun et al., 2011).

Models of land use change are characterised as apparatuses to help the investigation of the causes and results of land use change (Behera et al., 2012; Lopez et al., 2001) battle that solid land use land cover change Modelis required on the off chance that one has to know the future state and the spatial distribution of the land use land cover at Kenyir Lake Basin by employing the information from the earlier years that are historical land use change. There are a few strategies for land use land cover change prediction which include Cellular and Hybrid models, Markov Chain And Cellular Automata Analysis (Ca-Markov) Model (Katana et al., 2013). The CA-Markov Model is suitable for land use land cover simulations (Baysal, 2013; Hyandye \& Martz, 2017). This is because they consider spatiotemporal dynamics of land use land cover changes (Ghurah et al., 2018; Toriman et al., 2013).

A Markovian procedure is one in which the future condition of a classification can be modelled merely based on earlier state. This is expert by building up a transition probability matrix of land use land cover from time one to time two, which frames the reason for projection of future situations (Kamarudin et al., 2018). However, the objective of the current study is to develop land cover projection model using the CA- Markov analysis to predict the year 2030 land use land cover of Lake Kenyir River Basin dependent on the condition of land use land cover image of the year 2000 and 2009.

Urban growth, especially the development of residential and business land to provincial zones at the fringe of metropolitan regions, has for some time been viewed as an indication of regional economic imperativeness. However, its advantages are progressively adjusted against the ecosystem, comprising degradation of air and water quality and loss of forests cover, and socioeconomic impacts of financial variations, social discontinuity and infrastructural costs.

\section{Study Area and Methodology}

Kenyir Lake River Basin or Tasik Kenyir is the biggest man-made lake in south eastern Asia (Set et al., 2015 ; Kamarudin et al., 2018). It lies on latitude $05^{\circ} 00^{\prime} 14^{\prime \prime} \mathrm{N}$ and longitude $102^{\circ} 38^{\prime} 19^{\prime \prime} \mathrm{E}$. Kenyir Lake is situated in Hulu Terengganu region, about $50 \mathrm{~km}$ from Kuala Terengganu, in the territory of Kuala Terengganu which is one of the states in Malaysia. Kenyir Lake has more than 340 islands spread over the 38,000 hectares secured; it has more than 14 cascades. Kenyir Lake is flanked to Kelantan from the west and Pahang in the south; it has $260 \mathrm{~km}^{2}$ surface territories (Nouri et al., 2014). The climate of Kenyir Lake is tropical rainforest. Kenyir Lake has an average monthly temperature of $23^{\circ} \mathrm{C}$ to $31^{\circ} \mathrm{C}$ between March to November, while the average temperature falls below in December to February during the monsoon (Hyandye \& Martz, 2017). 


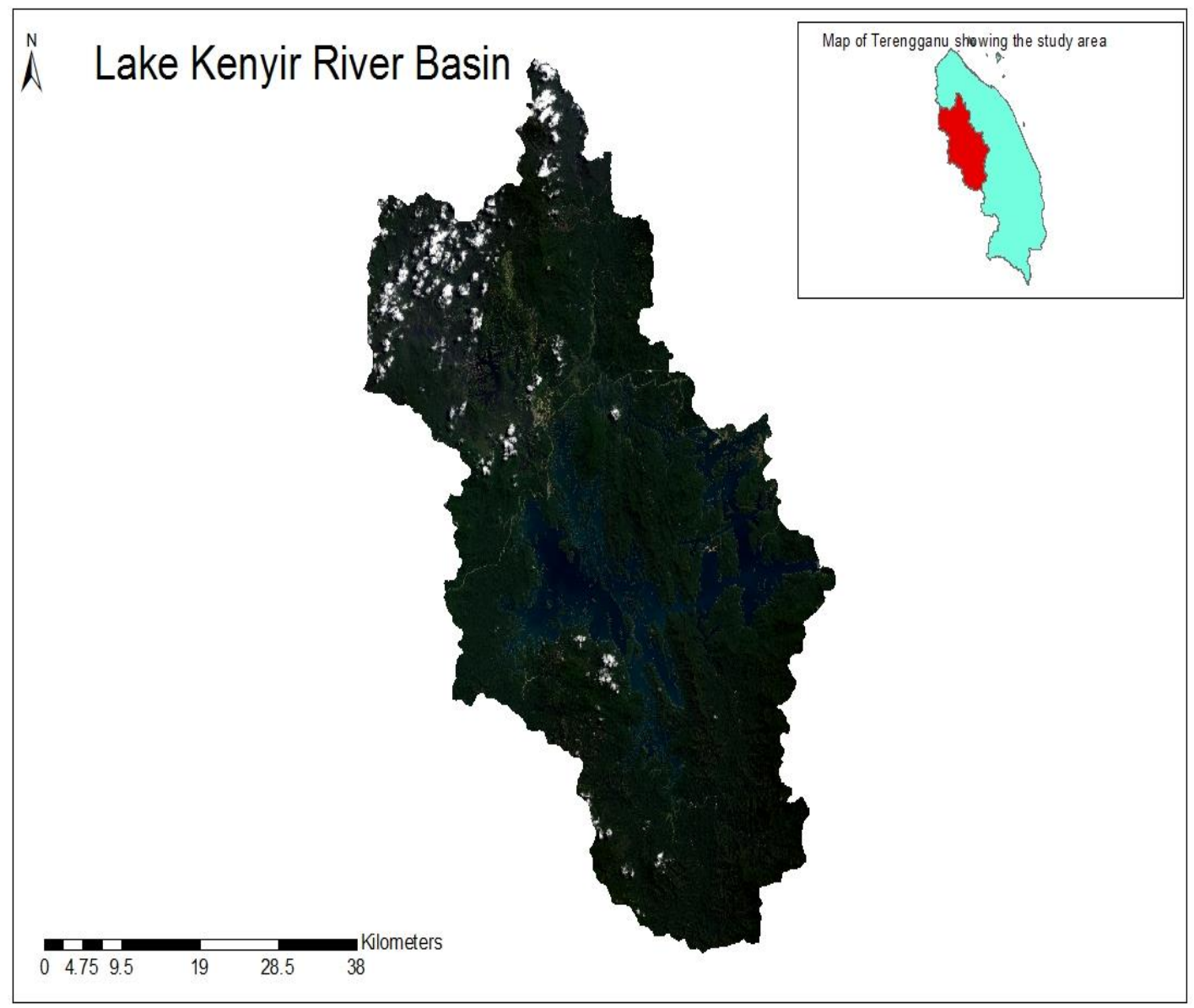

Figure 1: Image of the Study Area

\section{Data Sets and Methodology}

In this study secondary data is used in the form of Landsat images, these Landsat images are downloaded from the United State Geological Survey (USGS). Landsat images for the year 2001, 2009 and 2016 are used for the study. The supervised classification method of maximum likelihood algorithm was applied for the land use land cover classification to generate the classified images of 2001, 2009 and 2016. Landsat image for 2001, 2009, and 2016 are used in the study to analyse the historic land use land cover changes, the evolution of new land use class and finally to predict the land use land cover of lake Kenyir River Basin for the year 2030.

Markov analysis is a tool in remote sensing software which uses the transition probability matrix based on neighbourhood effects in a spatial influence algorithm (Hyandye \& Martz, 2017). Markov is a tool for modelling land use changes for setting "current trends" scenario; because it uses evolution from $(t-1)$ to $(t=0)$ to project probabilities of land use changes for a future date $(t+)$ (Pontius \& Neeti, 2010). 
Starting Markov process, using the classified land use land cover image for the year 2001 as (t -1) or the earlier and the classified land use land cover image of 2009 as $(t=1)$ or the later, this stage, generates transition probabilities matrix and transition areas matrix. Furthermore, the transition areas matrix expresses the total area (in cells) expected to change in the next period while transition probabilities matrix shows the likelihood of a pixel from one class changing to another class or within same class in the coming period (Khawaldah, 2016). For validation, which is an essential stage in the development of any land use land cover change prediction model (Khawaldah, 2016).

\section{Results and Discussion}

The validity of the Cellular Automata Markovian (CA-Markov) simulation was evaluated using multiple of base resolution statistical algorithms to measure the agreement and disagreement between two land use land cover images (Aburas et al., 2015). The agreements and disagreement between a set of two maps are measured regarding location and quantity of cells in each land use land cover class by computing the Kappa Indices of Agreement and disagreement statistics. For the CA-Markov model validation in the study, is the ability of the model to simulate correctly the land use land cover of Kenyir Lake River Basin to the year 2030. The validation involved using the real map (classified) of 2016 and projected land use land cover map 2016 generated from the Markov analysis result in the time series change module in IDRISI 16.0 to examine the strength/weakness of the CAMarkov model in future simulation. Figure 3 shows the images Kenyir Lake Basin to the analysis of the CA-Markov model ( $A$ and $B$ ), where $A$ is the projected image and $B$ the reference image.

Table 1: Validation Summary of Agreements and Kappa Indices

\begin{tabular}{cc}
\hline ITEMS & INDICES \\
\hline Agreement due to chance & 0.1250 \\
Agreement due to quantity & 0.2056 \\
Agreement due to location at the stratified level & 0.4067 \\
Agreement due to location at the grid cell level & 0.0204 \\
Disagreement due to location at the grid cell level & 0.0139 \\
Disagreement due to location at the stratified level & 0.0096 \\
Disagreement due to quantity & 0.0355 \\
Kappa for no information & 0.8339 \\
Kappa for grid-cell level location & 0.5934 \\
Kappa for stratum-level location & 0.8593 \\
Kappa Index of Agreement (Kappa Standard) & 0.6934 \\
\hline
\end{tabular}

However, the results from generated from the validation module shows the kappa coefficient (K) values for the validation in the study as Kstandard $=0.6934$ as seen in Table 1. Moreover, the Kappa coefficient values give the acceptable K-standard value of stimulation for a perfect prediction. Furthermore, the results are shown in Tables 2 the transnational probability matrix derived from the land use land cover map of 2001 and 2009 indicating the probability of land use land cover changing 
INTERNATIONAL JOURNAL OF ACADEMIC RESEARCH IN BUSINESS AND SOCIAL SCIENCES

Vol. 9, No. 2, Feb, 2019, E-ISSN: $2222-6990$ ๑ 2019 HRMARS

in 2030 within same category of land use land cover or to another class of land use land cover, and the area expected to change.

Table 2: Transition Probability Matrix Derived from Land Use Map 2001 and 2009 Probability of Changing to 2030

\begin{tabular}{cccc}
\hline Class & Built-Up & Vegetation & Water Body \\
\hline Built-up & 0.5412 & 0.4155 & 0.0433 \\
Vegetation & 0.8181 & 0.1336 & 0.0482 \\
Water body & 0.1446 & 0.318 & 0.8235 \\
\hline
\end{tabular}

The agreements and disagreement between a set of two maps are measured regarding location and quantity of cells in each land use land cover class by computing the Kappa Indices of agreement and disagreement statistics. For the CA-Markov model validation in the study, is the ability of the model to simulate correctly the land use land cover of Kenyir Lake Basin to the year 2030. The validation involved using the real map (classified) of 2016 and projected land use land cover map 2016 generated from the Markov analysis result in the time series change module in the Remote Sensing (RS) IDRISI 16.0 to examine the strength/weakness of the CA-Markov model in future simulation. Figure 2 shows the images Lake Kenyir River Basin to the analysis of the CA-Markov model (A and B), where $A$ is the projected image and $B$ the real or the classified image.

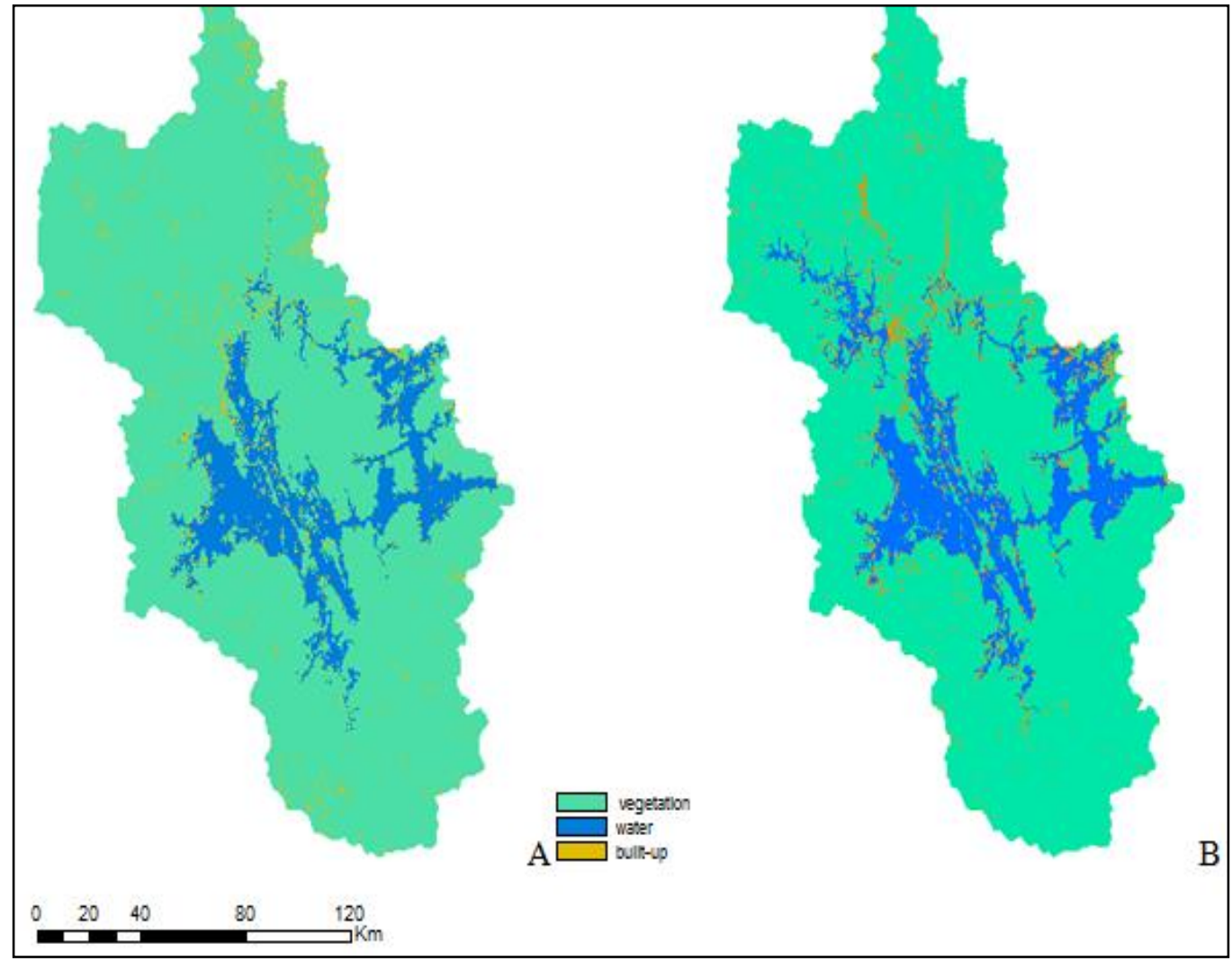

Figure 2: (A) Projected and (B) Classified Land Use Land Cover Image 2016 
INTERNATIONAL JOURNAL OF ACADEMIC RESEARCH IN BUSINESS AND SOCIAL SCIENCES

Vol. 9, No. 2, Feb, 2019, E-ISSN: $2222-6990$ ๑ 2019 HRMARS

\section{Projected Land Use for $\mathbf{2 0 3 0}$}

The simulation results also indicate a significant change of land use land cover in Kenyir Lake River Basin through the narrowing of vegetation cover to $2,062.6 \mathrm{~km}^{2}$ in 2016 compared to the area it will cover 2030 . The area covered by waterbody is expected to decrease slightly by 0.93 percent in the year 2030 as shown in Table 3. However, the result indicates an expected increase in built-up areas from the $117.03 \mathrm{~km}^{2}$ in 2016 to $220.36 \mathrm{~km}^{2}$ (as shown in Table 3), this could be a result of natural population growth or due to tourism, which has significant implications for the ecosystem in Lake Kenyir River Basin. Moreover, the projected land use land cover image of Lake Kenyir River Basin as Figure 4 indicate the total area covered by vegetation water body and built-up will $2,062.6 \mathrm{~km}^{2}$, $332.04 \mathrm{~km}^{2}$ and $220.36 \mathrm{~km}^{2}$ which is equivalent to 78.88 percent, 12.7 percent and 8.42 percent respectively. Provided the effect of climate change and other climatic events such as floods, excessive rain, government transitions and political interventions has not been considered in the current study, these factors have likely to affect the predicted situations.

Table 3: Amount of Changes in Land Use Base on the CA-Markov Model during 2016- 2030

\begin{tabular}{ccccccc}
\hline Year & \multicolumn{2}{c}{2016} & \multicolumn{2}{c}{2030} & \multicolumn{2}{c}{ Change 1976-2016 } \\
\hline LULC class & Area $\left(\mathrm{km}^{2}\right)$ & Area (\%) & $\begin{array}{c}\text { Area } \\
\left(\mathrm{km}^{2}\right)\end{array}$ & Area (\%) & Area $\left(\mathrm{km}^{2}\right)$ & Area (\%) \\
\hline Built-up & 117.03 & 4.48 & 220.36 & 8.42 & 103.33 & 3.94 \\
Vegetation & 2141.71 & 81.9 & 2062.6 & 78.88 & -79.11 & -3.02 \\
Water body & 356.26 & 13.62 & 332.04 & 12.69 & -24.22 & -0.93 \\
\hline
\end{tabular}

Table 4: Predicted Areas of Land Use Base on the CA-Markov Model for 2030 in the Study Area

\begin{tabular}{cccc}
\hline LULC Class & Built-up & Vegetation & Waterbody \\
\hline Area in $\left(\mathbf{k m}^{\mathbf{2}}\right)$ & 220.36 & 2062.6 & 332.04 \\
Area in percentage (\%) & 8.42 & 78.88 & 12.7 \\
\hline
\end{tabular}

The transition probabilities indicate a probability of 0.5412 for built-up to remain in its existing state and a probability of 0.4155 for built-up to change to vegetation and 0.0433 for built-up to change to water body. The conversion of built-up to water body categories shows a very lower probability as shown in Table 4. However, the transition probability of vegetation converting to built-up is 0.8181 while the probability of vegetation cover to remain in its existing state is very 0.1336 , which shows a higher chance of vegetation cover to remain unchanged, lower probability of 0.0482 of vegetation is likely to change to water body. Transition probability of 0.1446 for water body is likely to change to built-up, and probability of 0.3180 for water body to change to vegetation cover. A higher probability of 0.8235 of water body is expected to remain in the existing categories. The high transition probability from vegetation to built-up is mainly a result of an increase in the construction of social amenities in the Lake Kenyir Basin. 
The year 2030 simulated land use cover maps reveal a significant increase of built-up area. The land use land cover change detection statistics in Table 4 reveal that built-up will cover a land mass of 220 $\mathrm{km}^{2}$ which translate to 8.42 percent of the total area covered by Kenyir Lake River Basin. Moreover, vegetation will cover a total area of $2062.6 \mathrm{~km}^{2}$ translating to 78.88 percent, this shows the total area covered by vegetation will be reduced by 21.12 percent by the year 2030 . However the simulated land use land cover image for 2030 shows a decrease in water body to $332.04 \mathrm{~km}^{2}$ which translate to 12.7 percent compared to the year 2016. The dams of Puah Dam and Tembat Dam were omitted in the simulate image of 2030 as due to the inability of the IDRISI software due to capture the two dams constructed between 2013 and 2014 respectively. The potential drivers of the land use land cover changes in Kenyir Lake River Basin are increases in tourism and government expansion policy for both economic which is mainly tourism and electricity generation. The study results are consistent with studies conducted in other basins and tourism attraction zones in the Malaysia Peninsular and other global researches (Figure 3) (Lambin et al., 2001 ; Gidado et al., 2018).

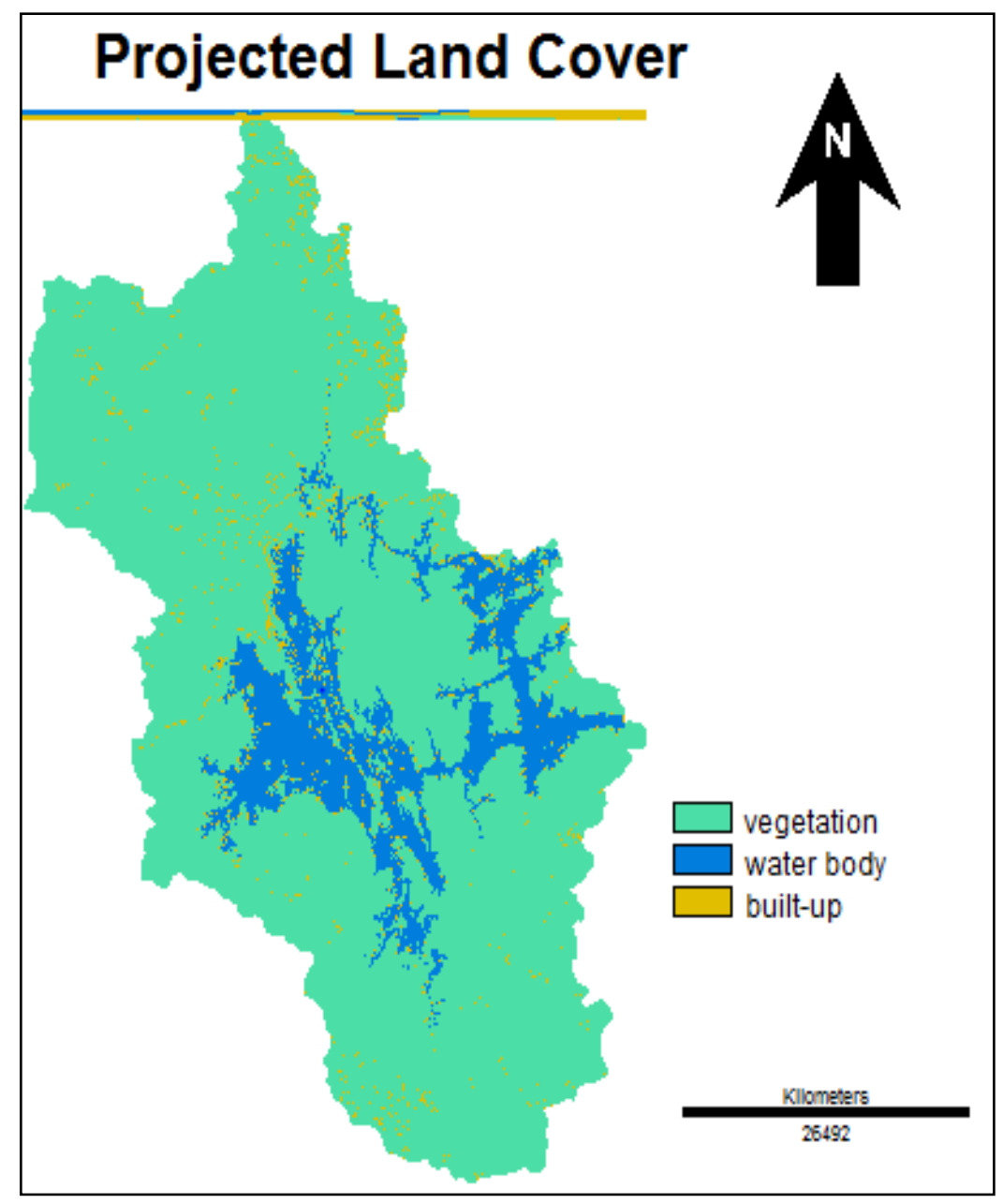

Figure 3: Stimulated land use land cover Map of Kenyir Lake River Basin 2030 
INTERNATIONAL JOURNAL OF ACADEMIC RESEARCH IN BUSINESS AND SOCIAL SCIENCES

Vol. 9, No. 2, Feb, 2019, E-ISSN: 2222-6990 C 2019 HRMARS

\section{Conclusion}

The CA-Markov chain analysis indicate the difference in one land use to another land use and further uses this to predict the future. Modelling of land use land cover change play an essential role in understanding the concepts of land use changes. The results further demonstrate that the Remote Sensing and GIS innovation is a compelling methodology in the analysis of land use change modelling using the CA- Markov. Finally CA- Markov analysis of land use land cover changes projected for the year 2030. The study is very important researchers to monitor of socio economic impact at Lake Kenyir in order protect the environment for sustainable development. Moreover, this finding would have a total perspective of things to come setting of urban land use which would guide the policy maker.

\section{References}

Aburas, M. M., Abdullah, S. H., Ramli, M. F., \& Ash'aari, Z. H. (2015). Measuring land cover change in Seremban, Malaysia using NDVI index. Procedia Environmental Sciences, 30, 238-243.

Baysal G. (2013) Urban land use and land cover change analysis and modeling a case study area Malatya, Turkey (Doctoral dissertation).

D Behera, M. U. K. U. N. D. A., Borate, S. N., Panda, S. N., Behera, P. R., \& Roy, P. S. (2012). Modelling and analyzing the watershed dynamics using Cellular Automata (CA)-Markov model-A geoinformation-based approach. Journal of earth system science, 121(4), 1011-1024.

Ghurah, M. H. A., Kamarudin, M. K. A., Wahab, N. A., Juahir, H., Lananan, F., Maulud, K. N. A., \& Zin, M. S. M. (2018). Assessment of urban growth and sprawl using GIS and remote sensing techniques in South Ghor region, Al-Karak, Jordan. International Journal of Engineering and Technology (UAE), 7(3.14 Special Issue 14), 5-11.

Gidado, K. A., Khairul, M., Kamarudin, A., Firdaus, N. A., Muhammad, A., Shakir, A., Ibrahim, S. (2018). Analysis of Spatiotemporal Land Use and Land Cover Changes using Remote Sensing and GIS : A Review, 7, 159-162.

Hyandye, C., \& Martz, L. W. (2017). A Markovian and cellular automata land-use change predictive model of the Usangu Catchment. International journal of remote sensing, 38(1), 64-81.

Islam, M. S., \& Ahmed, R. (2011). Land use change prediction in Dhaka city using GIS aided Markov chain modeling. Journal of Life and Earth Science, 6, 81-89.

Kamarudin, M. K. A., Gidado, K. A., Toriman, M. E., Juahir, H., Umar, R., Wahab, N. A., ... \& Maulud, K. N. A. (2018). Classification of Land Use/Land Cover Changes Using GIS and Remote Sensing Technique in Lake Kenyir Basin, Terengganu, Malaysia. International Journal of Engineering and Technology (UAE), 7(3.14 Special Issue 14), 12-15.

Kamarudin, M. K. A., Wahab, N. A., Juahir, H., Wan, N. M. F. N., Toriman, M. E., Ata, F. M., ... \& Azmee, S. H. (2018). The potential impacts of anthropogenic and climate changes factors on surface water ecosystem deterioration at Kenyir Lake, Malaysia. International Journal of Engineering and Technology (UAE), 7(3.14 Special Issue 14), 67-74.

Katana, S., Munyao, T., \& Ucakuwun, E. (2013). Hydrological impacts of land cover changes in upper Athi River Catchment, Kenya. International Journal of Current Research, 5(5), 1187-93.

Khawaldah, H. A. (2016). A Prediction of Future Land Use/Land Cover in Amman Area Using GIS-Based Markov Model and Remote Sensing. Journal of Geographic Information System, 8(03), 412. 
INTERNATIONAL JOURNAL OF ACADEMIC RESEARCH IN BUSINESS AND SOCIAL SCIENCES

Vol. 9, No. 2, Feb, 2019, E-ISSN: 2222-6990 C 2019 HRMARS

Lambin, E. F., Turner, B. L., Geist, H. J., Agbola, S. B., Angelsen, A., Bruce, J. W., ... \& George, P. (2001). The causes of land-use and land-cover change: moving beyond the myths. Global environmental change, 11(4), 261-269.

López, E., Bocco, G., Mendoza, M., \& Duhau, E. (2001). Predicting land-cover and land-use change in the urban fringe: a case in Morelia city, Mexico. Landscape and urban planning, 55(4), 271-285.

Lun, P. I., Gasim, M. B., Toriman, M. E., Rahim, S. A., \& Kamaruddin, K. A. (2011). Hydrological Pattern Of Pahang River Basin And Their Relation To Flood Historical Event. e-BANGI, 6(1), 9.

Nouri, J., Gharagozlou, A., Arjmandi, R., Faryadi, S., \& Adl, M. (2014). Predicting urban land use changes using a CA-Markov model. Arabian Journal for Science and Engineering, 39(7), 55655573.

Pontius, R. G., \& Neeti, N. (2010). Uncertainty in the difference between maps of future land change scenarios. Sustainability Science, 5(1), 39.

Set, K., Yaakop, A. Y., Hussin, N. Z. I., \& Mohd, B. (2015). Understanding Motivation Factors of Tourism Entrepreneurs in Tasik Kenyir. International Academic Research Journal of Social Science, 1(2), 248-254.

Toriman, M. E., Ata, F. M., Kamarudin, M. K. A., \& Idris, M. (2013). Bed-load sediment profile and effect of river bank erosion on river cross-section. American Journal of Environmental Sciences, 9(4), 292-300.

Verburg, P. H., de Nijs, T. C., van Eck, J. R., Visser, H., \& de Jong, K. (2004). A method to analyse neighbourhood characteristics of land use patterns. Computers, Environment and Urban Systems, 28(6), 667-690.

Verburg, P. H., van Eck, J. R. R., de Nijs, T. C., Dijst, M. J., \& Schot, P. (2004). Determinants of land-use change patterns in the Netherlands. Environment and Planning B: Planning and Design, 31(1), 125-150.

Wahab, N. A., Kamarudin, M. K. A., Gasim, M. B., Umar, R., Ata, F. M., \& Sulaiman, N. H. (2016). Assessment of total suspended sediment and bed sediment grains in upstream areas of Lata Berangin, Terengganu. International Journal on Advanced Science, Engineering and Information Technology, 6(5), 757-763. 